\title{
Godzenie skończoności i eschatologii u Rainera Marii Rilkego i T.S. Eliota
}

\section{Balance of Apocalypticism and Eschatology in Rainer Maria Rilke and T.S. Eliot}

Abstract: This text takes up the relation of the modernist lyric (Rainer Maria Rilke and T.S. Eliot) to Martin Heidegger's existentialist conception of time and the naturalistic anthropology it has spawned. Building on that, I argue that Rilke's Duino Elegies not only anticipate central motifs of existentialism but, in qualified ways, part ways with that outlook. I then take up the second of Eliot's Four Quartets to show that, more emphatically than Rilke, Eliot maintains that poetry of any substance can only be written insofar as it is grounded in an eschatological framework. East Coker in particular shows Eliot's seeking to balance the apocalypticism of a world once again mired in global warfare with a hope, however, subdued, for mankind's eventual redemption.

Keywords: Rainer Maria Rilke, T.S. Eliot, Martin Heidegger, modernism, eschatology, existentialism, theology

Streszczenie: Artykuł podejmuje kwestię związku liryki modernistycznej (Rainera Marii Rilkego i T.S. Eliota) z egzystencjalistyczną koncepcją czasu Martina Heideggera i zrodzoną przez tę ostatnią naturalistyczną antropologią. Na tej podstawie autor stwierdza, że Elegie duinejskie Rilkego nie tylko antycypują centralne motywy egzystencjalizmu, ale także w pewien sposób separują się od tej perspektywy. Następnie sięga do drugiego z Czterech kwartetów, aby pokazać, że bardziej zdecydowanie niż Rilke Eliot twierdzi, że wszelka poezja może być napisana tylko wtedy, gdy jest osadzona w eschatologicznych ramach. W szczególności East Coker ukazuje Eliota, który stara się zrównoważyć apokaliptyczny charakter świata ponownie pogrążonego $\mathrm{w}$ globalnej wojnie z nadzieją, jakkolwiek stonowaną, na ostateczne odkupienie ludzkości.

Słowa kluczowe: Rainer Maria Rilke, T.S. Eliot, Martin Heidegger, modernizm, eschatologia, egzystencjalizm, teologia 


\section{I}

Tematem mojego wykładu ${ }^{1}$ jest trwałość motywów eschatologicznych w poezji współczesnej na przykładzie późnych dzieł dwóch spośród największych poetów dwudziestowiecznych: Rainera Marii Rilkego i T.S. Eliota. Już samo poruszenie tego problemu oznacza niezgodę z większością ustaleń literaturoznawczych ostatnich pięćdziesięciu lat, które zazwyczaj ignorowały lub całkowicie odrzucały pytania o eschatologię i transcendencję jako pozbawione znaczenia dla tego, co uznaje się za całkowicie sekularną współczesność. Integralną częścią tego założenia jest naturalistyczny model człowieka, który dominował w zachodniej kulturze intelektualnej od czasów Davida Hume’a i Woltera. Patrząc z tej perspektywy - wszyscy się rodzimy, poświęcamy czas na różne zajęcia, a gdy się on wyczerpie, umieramy, zgodnie z uśrednionymi statystykami dla danej grupy. Czas pojmowany jest ściśle chronometrycznie, jako materia ubywania czy czysto fizyczna „przewidywana długość życia”. W takim czasie nie ma treści, pełni, wzorców, znaczeń czy obecności. Nigdy nie może on się stać przedmiotem doświadczenia per se, ponieważ - jak twierdził już Immanuel Kant - czas jest tylko warunkiem formalnym możliwości zaistnienia wszelkiego potencjalnego doświadczenia. Nieustannie odchodzi on w niepamięć, jest tylko coraz cieńszą nicią, za pomocą której mierzymy ,jeszcze nieprzewidywanej” (lub budzącej grozę) przyszłości, która zbliża się do niedostrzegalnego progu teraźniejszości tylko po to, by zniknąć w „już nie” przeszłości. Krótko mówiąc, w naturalistycznych i antropomorficznych ramach konceptualnych czas wciąż się „zużywa”, poświęca, traci, marnuje, trawi; z tego powodu bieżące doświadczenie traci znaczenie i pełnię już wtedy, gdy tylko ono nastąpi.

Jak się okazuje, ta naturalistyczna koncepcja czasu istotnie zmieniła też naszą koncepcję znaczenia. $Z$ naturalistycznego punktu widzenia znaczenie nie może być darem (już sama koncepcja daru od dawna była podejrzana), lecz jest jedynie tym, co ludzkie podmioty wytwarzają w ramach skończonego, sekwencyjnego czasu. Znaczenie nigdy nie było pojmowane czy opisywane jako transcendentny „wzorzec” (termin kluczowy w Czterech kwartetach Eliota), lecz uznawano je zaledwie za kolejny wytwór homo faber, który rzeczywistość pojmuje jako coś wytworzonego i wymiennego, nigdy zaś jako dar. Rzeczywistość jest jedynie sumą twierdzeń, jakie potrafimy sformułować na jej temat, jest ogółem informacji i jako taką definiuje ją wyłącznie jej wartość użytkowa. $Z$ tego powodu nasz stosunek do przyszłego czasu podpada niemal w całości pod jurysdykcję pragnienia, nie nadziei, przez co łakniemy przyszłości wypełnionej po brzegi obietnicami i odczuciami. Paradoksalnie człowieka nowoczesnego napawa strachem także potencjalność natury czasu

1 Poniższy tekst zaprezentowany został jako wykład gościnny na Wydziale Polonistyki Uniwersytetu Jagiellońskiego w czerwcu 2018 roku. 
przyszłego, co wyjaśnia chętne antycypowanie i przewidywanie przez nas przyszłości za pomocą sondaży politycznych, prognoz ekonomicznych i poszukiwania wszelkiego rodzaju „trendów”. Przyszłość jest bowiem pożądana, tylko jeśli potwierdza jakiś rodzaj narracji o „postępie”, której chcielibyśmy być bohaterami. Nie powinna to być po prostu przyszłość, lecz stanowczo nasza przyszłość - przyszłość, która będzie się toczyć na naszych zasadach, zgodnie ze wskaźnikami umożliwiającymi nam jej przewidywanie i minimalizowanie jej przypadkowej natury.

Scenariusz, który właśnie zakreśliłem, nieuchronnie musi przypominać Heideggerowską koncepcję czysto immanentnej i skończonej egzystencji, czyli Dasein („jestestwo”). Czysto immanentną egzystencję współczesną definiuje jej niezdolność do uznania własnego istnienia. Egzystencji nie da się ująć w twierdzenia, lecz doświadcza się jej całościowo w formie, którą Heidegger nazywa Befindlichkeit lub Stimmung, co chyba najlepiej tłumaczy się jako „nastrój” lub „tryb” [w polskim tłumaczeniu Befindlichkeit to „położenie”, a Stimmung - „nastrój"]. Chyba najmocniej rzucającym się w oczy nastrojem charakteryzującym Dasein jest „trwoga” (Angst). Jak powiada Martin Heidegger, „tym, przed czym trwoga się trwoży, jest samo bycie-w-świecie"2. Jest to nastrój podstawowy dla egzystencji współczesnego człowieka - „trwoga jako modus położenia otwiera świat jako świat" ${ }^{\prime \prime} \mathrm{Z}$ tego powodu zdaje się przeciwieństwem eschatologicznej nadziei. Wszelka wiedza, jaką Dasein jest zdolne uzyskać na temat tego świata, do którego zostało wrzucone, nie mogąc kiedykolwiek poczuć się w nim jak u siebie, jakiekolwiek zrozumienie i egzegezę otaczających je bytów, tradycji, języków, systemów i wartości mogłoby zdobyć - wszystko to zawsze rozpada się z powodu przyszłości, która przeraża dlatego, że jest lub nie jest całkowicie przewidywalna. Choć Heidegger opisuje koncepcję immanentnej, skończonej i antropomorficznej egzystencji w niespotykanie surowych kategoriach, nie jest ona pozbawiona precedensu i przypomina radykalny augustynizm Marcina Lutra, Jana Kalwina, Blaise’a Pascala i Sørena Kierkegaarda. Pamiętamy też jak Pascal określa ludzi XVII stulecia: „błąkamy się w czasach, które nie są nasze”“; jak mówi: „stan człowieka: niestałość, nuda, niepokój”' (inconstance, ennui, misère), człowiek „nie może wiedzieć, ani nie pragnąć wiedzieč”.

U Rilkego jeden z najbardziej zapadających w pamięć obrazów poczucia dezorientacji i pustki definiujących współczesną egzystencję, nieustannie pragnącej afirmacji ze strony innych ludzi, wiąże się z grupą akrobatów opisaną w Elegii piatej ze zbioru Elegii duinejskich. Akrobaci ci (Les Saltimbanques-

\footnotetext{
2 M. Heidegger, Bycie i czas, tłum., przedm., przyp. B. Baran, Warszawa 2004, s. 239.

3 Tamże.

${ }^{4}$ B. Pascal, Myśli, tłum. T. Żeleński (Boy), Warszawa 1968, s. 95 (nr 168; 21; 172).

5 Tamże, s. 93 (nr 199; 79; 127).

${ }^{6}$ Tamże, s. 156 (nr 367; 73; 389).
} 
Rodzina kuglarzy), przedstawieni przez Pabla Picassa na obrazie, który Rilke miał okazję oglądać w trakcie pobytu w roku 1915 w mieszkaniu swojej przyjaciółki Herthy König, wydają się:

nieco jeszcze szybciej niż my mijający, których od rana

urabia, komu, komu na uciechę

nigdy niesyta Wola?

Ta grupa wykonawców wydaje się całkowicie pozbawiona bytu, zredukowana do tego, że się „podrzuca ich w górę, łapie na nowo" ła ograniczona do scenicznej śmiałości. Są to linoskoczkowie „wędrowni” (die Fahrenden), a ich życie to niewiele więcej niż pusty, wciąż powtarzany występ na linie, mający spowodować aplauz wśród pozbawionych twarzy i korzeni mieszkańców jakiegoś nędznego paryskiego przedmieścia. To najpewniej Friedrich Nietzsche uczulił Rilkego na emblematyczną figurę akrobaty. Pamiętamy istotny ustęp z przedmowy do Tako rzecze Zaratustra:

Człowiek jest liną rozpiętą między zwierzęciem i nadczłowiekiem - liną ponad przepaścią. Niebezpieczne to przejście, niebezpieczne podróże, niebezpieczne wstecz poglądanie, niebezpieczne trwożne zachwianie i zatrzymywanie się. Oto, co wielkiem jest w człowieku, iż jest on mostem, a nie celem; oto, co w człowieku jest umiłowania godnem, że jest on przejściem i zanikiem (dass er ein Ubergang und ein Untergang ist) ${ }^{9}$.

Elegie duinejskie Rilkego i wcześniejsza poezja Eliota, z kulminacją w postaci Ziemi jatowej, zapowiadając słowa Heideggera o czasie jako czystym „rozszerzaniu się" (Erstreckung) i o wynikającej z tego utracie znaczącego doświadczenia przez Dasein, zawierają wiele dystopijnych scenariuszy jak te już wspomniane. Jeszcze w pierwszym z Czterech kwartetów, Burnt Norton z 1936 roku, Eliot przywołuje obraz twarzy „, przeoranych czasem i napiętych, (...) pełnych fanaberii a pozbawionych sensu"10 (w. 103-105), dryfujących bez celu i nadziei przez miejskie kontinuum czasoprzestrzenne, których widmowa egzystencja przypadkowo objawia się nam, nie im:

(...) w metrze, gdy pociąg zbyt długo stoi pomiędzy stacjami

I rozmowa narasta, a potem $\mathrm{z}$ wolna przechodzi w milczenie,

7 R.M. Rilke, Elegia piąta [w:] tegoż, Elegie duinejskie, tłum. M. Jastrun, Kraków 1962, s. 29.

8 Tamże.

9 F. Nietzsche, Tako rzecze Zaratustra, tłum. W. Berent, Kraków 2014, s. 12.

${ }_{10}$ T.S. Eliot, Cztery kwartety: Burnt Norton, tłum. K. Boczkowski [w:] tegoż, Wybór poezji, wyb. K. Boczkowski, W. Rulewicz, wstęp W. Rulewicz, Wrocław 1990, BN II 230, s. 240. 
I widzisz poza każdą twarzą coraz głębszą pustkę

I wzrastające przerażenie - że nie ma o czym myśleć (East Coker, w. 119-122) ${ }^{11}$.

W taki właśnie sposób Eliot często przedstawia londyńczyków - „forma (...) nie ogranicza (...). Pomiędzy niebytem a bytem” (Burnt Norton, w. 169, 171). Zatem na pierwszy rzut oka portrety współczesnej egzystencji autorstwa Rilkego i Eliota, wraz z ramami stanowiącymi ich podstawę, zdają się dokładnym przeciwieństwem eschatologii chrześcijańskiej z jej visio beatifica („wizją uszczęśliwiającą”), wynikającą ze wzajemnego oddziaływania Bożej łaski i życia zasadzającego się na rozwijaniu w sobie cnót, zwłaszcza zaś cnoty nadziei, wiary i miłości.

Tymczasem wedle mojej dzisiejszej tezy, sprzecznej z tą intuicją, w rzeczywistości tak nie jest. Bardziej wyważona i dogłębna lektura dzieł tych poetów pozwala odkryć, że ich podejście do poezji łączy się z ciągłym, dialektycznym ruchem, tam i z powrotem między kondycją radykalnej skończoności i nieusuwalnym wymiarem transcendentnym, nieoczekiwanie odkrywającym się w ulotnych epifaniach. Dlaczego miałoby tak być? Dowodzę tutaj, że, mówiąc wprost, nie można sobie wyobrazić poezji - podobnie jak każdej innej formy sztuki - bez wymiaru transcendentnego, a dokładniej, eschatologicznego. Bowiem znaczenia tworzone przez słowo poetyckie nie podpadają pod kategorię homo faber. Przywołując stare rozróżnienie scholastyczne, nie są przykładami „robienia, czynienia” (facere), lecz „stwarzania” (creare). Słowo poetyckie nie wyraża twierdzeń ani nie przekazuje informacji; ono raczej zaprasza odbiorcę, by stał się uczestnikiem - a posługując się terminologią teologiczną, komunikantem - w prawdzie. Tym samym znaczenia kreatywnie odsłaniane przez słowo poetyckie należą raczej do porządku ujawniania (disclosure) niż prawidłowości (correctness; Edmund Husserl); chociaż poezja czerpie z prozaicznych zjawisk i spraw codziennych, to nigdy nie twierdzi po prostu, co wedle czysto immanentnych poglądów jest w nich „właściwego” czy „prawidłowego”. Słowo poetyckie raczej odsłania w obrębie skończonej egzystencji prawdy, bez których jej ograniczeni przez czas odbiorcy pozostawaliby bytami mniejszego formatu, a wręcz bytami niepełnymi. Dlatego też, choćby implicite i nieświadomie, słowo poetyckie z samej swej natury ukierunkowane jest na zbawianie swojego odbiorcy. Obraz poetycki nie jest ograniczony przez żadne kwestie pragmatyczne i zapowiada wspólnotę zakorzenioną w prawdzie - prawdzie będącej nie wynikiem woli czy zamiaru, lecz otrzymanej jako dar. Mowa poetycka z definicji nie może zostać wchłonięta przez zmienną, podatną na manipulacje i sporną domenę informacji. Przyjrzyjmy się pokrótce czterem głównym doktrynom chrześcijańskiej eschatologii, by móc się skupić na postulowanych przeze mnie eschatologicznych implikacjach mowy poetyckiej:

${ }^{11}$ Tenże, Cztery kwartety: East Coker, tłum. K. Boczkowski [w:] tegoż, Wybór poezji, dz. cyt., s. 266. 
1. Eschatologia jako doktryna o rzeczach ostatecznych odnosi się nie do punktu końcowego w czasie, lecz do zniesienia czasu zwykłego, ludzkiego - tego, co Augustyn nazwał „czasem-pamięcią”. Eschaton, koniec wszystkiego, nierozerwalnie spleciony z ideą zmartwychwstania i nieśmiertelności duszy, jest korelatem nadziei ukierunkowanej na stan poza czasem chronometrycznym. Nie jest to jakiś apokaliptyczny, zamykający akt skończonego, antropomorfizowanego czasu. Uznanie go za domknięcie czasu ludzkiego, nie zaś przekroczenie go, oznaczałoby przyjęcie tego, co od czasów Carla Schmitta i Leo Straussa określano mianem „teologii politycznej”. Z kolei, jak zauważył Joseph Ratzinger, teologia polityczna „deprecjonuje (...) nadzieję, kierując ją na pozór ku realiom”, i zastępuje zarówno wiarę, jak i politykę, „fałszywymi namiastkami”"12.

2. Wykraczając poza śmierć rozumianą jako całkowite unicestwienie, chrześcijański eschaton rozwiązuje rozbitą i nieuporządkowaną egzystencję człowieka w tym świecie. Dla Starego Testamentu charakterystyczna jest wizja śmierci jako zstąpienia w zaświaty (do Szeolu), z których zmarli nigdy nie wrócą i, jako że są umarli, trwają tam w stanie wiecznej i całkowitej izolacji. Taka izolacja, sfera, której „istotą jest opuszczenie, izolacja, samotność - a przez to wydanie człowieka nicości” ${ }^{13}$, z pewnością często definiuje ludzkie istnienie na tym świecie, co w przejmujący sposób wyraża zarówno Rilke, jak i Eliot - „istotą śmierci jest wyrwanie $\mathrm{z}$ wszystkich więzi” ${ }^{14}$.

3. Eschaton nie może być zaplanowany ani nie można go przewidzieć jako określonego wydarzenia w historii (zob. Łk 17, 20: „Królestwo Boże nie przyjdzie dostrzegalnie" [non venit regnum Dei cum observatione]). Katolicka teologia konsekwentnie (a od XIII wieku definitywnie) odrzucała wszelkie chiliastyczne (ewolucyjne) koncepcje historii, próbujące przewidywać koniec świata. Właśnie odrzucając koncepcję, „wedle której definitywne dopełnienie się świata jest możliwe i nastąpi w ramach jego dziejów” ${ }^{15}$, teologia eo ipso odrzuciła „oczekiwania na ostateczne zbawienie świata w wewnętrznym toku jego historii” ${ }^{16}$.

4. Niemniej, choć eschaton całkowicie wykracza poza porządek czasu, jest już z nami i wśród nas. Objawia się tu we fragmentach, odłamkach i znakach, takich jak epifaniczne momenty intensywnego, pozaczasowego doświadczenia ${ }^{17}$.

12 J. Ratzinger, Śmierć i życie wieczne, tłum. M. Węcławski, Warszawa 2000, s. 61.

13 Tamże, s. 81.

14 Tamże, s. 82.

15 Tamże, s. 194.

16 Tamże.

17 Jak ujął to Hans Urs von Balthasar: „wiara, nadzieja i miłość przechodzą przez fragmentaryczną egzystencję ku jeszcze niezgłębionemu spełnieniu. Dlatego mogą nabrać podejrzeń, jeśli ich pełnia zostanie im zawczasu oznajmiona i przedłożona. To właśnie fragmentaryczna natura człowieka i świata zaświadcza o tym, co autentyczne. Tak jak człowiek ślepy wprawnymi dłońmi wyczuje ostre krawędzie potłuczonych skorup, tak też cnoty w przełomowych chwilach egzystencji zdobywają wiedzę o kierunku, w jakim nastąpi spełnienie zaplanowane przez Boga”. H.U. von Balthasar, Das Ganze im Fragment, Einsiedeln 1963, s. 116 [tłumaczenie: J. Czernik za T. Pfau]. 
Cóż jeszcze może powiedzieć poeta w czasie, gdy cywilizacje planują i przeprowadzają industrialną rzeź na masową skalę? Kryzys, na który remedium mają stanowić elegie Rilkego między rokiem 1912 a 1922, to także kryzys głosu, który przemawia w tych wierszach. Poeta nie jest jedynie komentatorem dramatu współczesnej, wykorzenionej egzystencji oraz czasów na pozór pozbawionych nadziei i transcendentnego punktu odniesienia. Poeta musi też szukać w samym sobie odpowiedzi na pytanie o to, czy mająca znaczenie egzystencja jest możliwa w świetle tego, co Rilke nazywa „tym życiem zawieszonym nad przepaścią" (dieses ins Bodenlose gehängte Leben). Alter ego Rilkego, Malte Laurids Brigge, zadaje te pytania egzystencjalne:

Czy to być może (...), że się jeszcze nic rzeczywistego ani ważnego nie widziało, ani poznało, ani rzekło? (...) Czy to być może, iż mimo wynalazków i postępu, mimo kultury, religii i mądrości świata pozostało się na powierzchni życia? (...) Czy to być może, że całą historię świata zrozumiano fałszywie? (...) czy możliwe jest przypuszczenie, że można mieć Boga, nie zużywając Go?

Tak, jest możliwe.

Jeśli wszakże wszystko to jest możliwe (...), to wtedy, na miłość boską, musi się coś stać! [dann muss etwas geschehen] ${ }^{18}$.

Widać tu dialektyczny związek między skończonością i transcendencją, na który wskazywałem wcześniej. Rilke zakłada, że ludzkie istnienie stało się dla samego siebie niemal całkowicie nieprzejrzyste. Wydaje się, że załamały się nie tylko ramy religijne i metafizyczne, ale także współczesne świeckie i pragmatyczne schematy objaśniania. Co więcej, istoty ludzkie zazwyczaj nie chcą nawet konfrontować się z problemem istnienia, lecz zadowalają się życiem wypełnionym rozrywkami, podporządkowywaniem się normom i powierzchownością. Jednakże skoro kategoria całkowicie skończonej, immanentnej formy egzystencji stała się przedmiotem refleksji, głos poetycki nie może się zamykać w tych ramach. Uzyskawszy wgląd w temporalną skończoność egzystencji, zauważa niewystarczalność ściśle immanentnej koncepcji egzystencji. Poezja musi się teraz skonfrontować $\mathrm{w}$ sobie $\mathrm{z}$ transcendentnym wymiarem przesłoniętym przez konwencje społeczne, pozyskaną wiedzę, spisaną historię i życie powszechnie przeżywane jedynie powierzchownie. Elegie duinejskie Rilkego rodzą się z napięcia między konwencjonalną wypowiedzią a „krzykiem” (Schrei) protestu przeciw niewystarczalności powszedniej egzystencji i śledzą dialektykę łączącą czystą immanencję z niewyrażalną transcendencją. Napięcie to, w elegiach Rilkego często

${ }_{18}$ R.M. Rilke, Malte. Pamiętniki Malte-Lauridsa Brigge, tłum. W. Hulewicz, s. 8-9, https://wolnelektury.pl/media/book/pdf/rilke-malte.pdf, dostęp: 19.03.2020. 
obrazowane jako napięcie między „ja” lirycznym a postacią ,anioła” (Engel), może zilustrować kilka spostrzeżeń dotyczących pierwszej z Elegii duinejskich:

Wer, wenn ich schriee, hörte mich denn aus der Engel

Ordnungen? und gesetzt selbst, es nähme

einer mich plötzlich ans Herz: ich verginge von seinem

stärkeren Dasein. Denn das Schöne ist nichts

als des Schrecklichen Anfang, den wir noch grade ertragen,

und wir bewundern es so, weil es gelassen verschmäht,

uns zu zerstören. Ein jeder Engel ist schrecklich.

Und so verhalt ich mich denn und verschlucke den Lockruf

dunkelen Schluchzens. Ach, wen vermögen

wir denn zu brauchen? Engel nicht, Menschen nicht,

und die findigen Tiere merken es schon,

daß wir nicht sehr verläßlich zu Haus sind

in der gedeuteten Welt.

Któż, gdybym krzyknął, usłyszałby mnie z zastępów

anielskich? a gdyby nawet któryś z aniołów

przycisnął mnie nagle do serca: musiałbym umrzeć

od jego silniejszej istoty. Albowiem piękno jest tylko

przerażenia początkiem, który jeszcze znosimy

z takim podziwem, gdyż beznamiętnie pogardza

naszym unicestwieniem. Straszliwy jest każdy anioł.

Więc się powściągam i dławię zaklinające wołanie

ciemnego łkania. Ach, któż mógłby nam być

użyteczny? Nie aniołowie, nie ludzie,

a przemyślne zwierzęta już są na tropie,

że nie jesteśmy bezpiecznie zadomowieni w świecie,

który chcemy zrozumieć (Pierwsza elegia, w. 1-13) ${ }^{19}$.

„Zastęp anielski” oznacza wiedzę całkowicie niedostępną dla bytów skończonych. Zatem wszelkie bezpośrednie porozumienie między tymi dwiema domenami byłoby niemożliwe, a może nawet niepożądane. Tak czy inaczej, transcendentny „zastęp” nie jest niczym, nie jest jedynie projekcją. W rzeczywistości elegie Rilkego mówią właśnie o wiedzy („wissend um euch” - „wiedzący o was”, Druga elegia, w. 3) i że zastępy anielskie są nieosiągalne. Stosowne zatem jest to, że Druga elegia rozpoczyna się od nawiązania do postaci Tobiasza z apokryficznej ${ }^{20}$ księgi zatytułowanej od jego imienia. Tak jak Tobiasz nie był świadom tego,

19 R.M. Rilke, Pierwsza elegia [w:] tegoż, Elegie duinejskie, dz. cyt., s. 17.

${ }^{20}$ Księga Tobiasza, dla katolików kanoniczna, jest przez różne Kościoły protestanckie traktowana jako apokryf [przyp. tłum.]. 
że w podróżach towarzyszy mu anioł, tak i Engel Rilkego znajduje się w sferze transcendentnej, względem której istoty ludzkie ciągle okazują się niewystarczające, ale której z tego właśnie powodu nie mogą ani odrzucić, ani zignorować. Transcendentny zastęp jest prawdziwy nie dlatego, że możemy na jego temat wygłosić twierdzenia o charakterze pozytywnym, lecz dlatego, że dostrzegamy, iż całkowicie skończona, immanentna egzystencja jest w ogóle niemożliwa.

Głębokie poczucie utraty i niewystarczalności trapiące czystą immanencję wynika też, przynajmniej częściowo, z naszej nieudolnej reakcji na pełnię danego nam świata zjawisk. Rilke już w Nowych poezjach (z 1907 roku) próbował uchwycić epifaniczną pełnię w widzialnej, konkretnej, otaczającej nas rzeczywistości. Także Elegie duinejskie nie mówią o transcendencji jako o odwróceniu się od świata, ale przeciwnie - jako o czymś przelotnie dostrzegalnym dzięki otwartemu przyjmowaniu przez nas egzystencji. Uznanie, że „byt ziemski jest wspaniały" (Hiersein ist herrlich - Siódma elegia), oznacza wyparcie się transcendencji tylko o tyle, o ile powszechnie rozumiało się ją jako jakieś wyobrażone, empirejskie życie po śmierci. Tymczasem transcendencja okazuje się kusząco bliska, gdy tylko otworzymy się na to, co Rilke uznaje za odmienny, nieeuklidesowy rodzaj „przestrzeni” (Raum). Przenika ona noc („die Nacht, wenn der Wind voller Weltraum/ uns am Angesicht zehrt” - „noc, gdy wicher pełen przestworów/ niszczy nam twarz" - Pierwsza elegia, w. 18-19), przestrzeń pozorną niezanieczyszczoną przez rzeczy, obietnice, pragnienia. Ta domena, w której język nie został zepsuty pragnieniem (Werbung), znajduje się z dala od retoryki - jest to przestrzeń wypełniona całkowicie prostolinijnym dawaniem i odbieraniem, najbardziej uważnym słuchaniem, a ostatecznie ciszą:

Wirf aus den Armen die Leere

zu den Räumen hinzu, die wir atmen; vielleicht daß die Vögel

die erweiterte Luft fühlen mit innigerm Flug. (...)

Stimmen, Stimmen. Höre, mein Herz, wie sonst nur

Heilige hörten: daß die der riesige Ruf

aufhob vom Boden; sie aber knieten,

Unmögliche, weiter und achtetens nicht:

So waren sie hörend. Nicht, daß du Gottes ertrügest

die Stimme, bei weitem. Aber das Wehende höre,

die ununterbrochene Nachricht, die aus Stille sich bildet.

Dorzuć z ramion twych próżnię

do oddychalnych przestrzeni; a może ptaki

poczują lotem wnikliwszym rozszerzone powietrze. (...)

Głosy, głosy. Nasłuchuj, moje serce, jak jeszcze

tylko święci słuchali: aż potężne wezwanie

unosiło ich ponad ziemię, lecz oni klęczeli dalej,

Nieprawdopodobni, i nie zważali na to: 
tak byli zasłuchani. Nie, żebyś mógł i zdołał przetrzymać głos Boga. Lecz słuchaj wielkiego powiewu,

tej nieprzerwanej wieści, która kształtuje się w ciszy (Pierwsza elegia, w. 23-25, $54-60)^{21}$.

Istotę Pierwszej elegii stanowią owa tęsknota za bezruchem, ciszą i całkowite zestrojenie się z czystą przestrzenią. To dążenie do stanu zwiększonej receptywności, lecz nie wobec głosu Boga (którego „nie mógłbyś i nie zdołał przetrzymać”), lecz wobec „wielkiego powiewu/ tej nieprzerwanej wieści, która kształtuje się w ciszy”. Zgodnie z tradycją ukształtowaną przez Pascala i św. Jana od Krzyża celem dążeń Rilkego jest stan całkowitej samotności i ciszy, który umożliwi głosowi lirycznemu uchwycenie „tej nieprzerwanej wieści, która kształtuje się w ciszy” („die ununterbrochene Nachricht, die aus Stille sich bildet”). Z ową „ciszą” (Stille) blisko związany jest stan „wyciszenia” (gestillt) dzięki pełnej znajomości i akceptacji samotności i śmiertelności. „Porzuceni” (die Verlassenen - wers 38) ostatecznie przewyższają "kochających”, których pragnienie zostało „zaspokojone” (die Gestillten - wers 39). U Rilkego i - jak za chwilę zobaczymy - u Eliota „cisza” (Stille) utrudnia zwykłe zaspokajanie skończonych („ontycznych”) pragnień. Wskazuje ona na eschaton poza obszarem pragnienia, retoryki i współczesnego, ściśle antropomorficznego modelu czasu jako ciągłego „postępu”. W poszukiwaniu przez Rilkego ciszy słyszymy echa „niespokojnego serca” (cor inquietus) Augustyna, pragnącego „spoczać w Tobie” (requiescat in te). Eschaton Rilkego przypomina stoicką ataraksję, a zwłaszcza prawosławną ideę kenozy, i zawiera nie tyle ostateczną wizję uszczęśliwiającą, ile raczej kategoryczne zerwanie z zaburzoną domeną pragnienia oraz uznanie skończonej egzystencji zarówno za niemożliwą, jak i nieodpartą. Telos nie jest utopią pochodzącą z tego lub nie z tego świata, lecz dążeniem doczesnego życia, jak strzała na naciągniętej cięciwie łuku, „aby skupiona w odskoku/ była czymś więcej niż jest” (um gesammelt im Absprung/ mehr zu sein als er selbst - w. 52-53):

Freilich ist es seltsam, die Erde nicht mehr zu bewohnen,

kaum erlernte Gebräuche nicht mehr zu üben,

Rosen, und andern eigens versprechenden Dingen

nicht die Bedeutung menschlicher Zukunft zu geben;

das, was man war in unendlich ängstlichen Händen,

nicht mehr zu sein, und selbst den eigenen Namen

wegzulassen wie ein zerbrochenes Spielzeug.

Seltsam, die Wünsche nicht weiterzuwünschen. Seltsam,

alles, was sich bezog, so lose im Raume

${ }^{21}$ R.M. Rilke, Pierwsza elegia, dz. cyt., s. 17-18. Wydanie oryginalne cytowano w artykule za: https://de.wikisource.org/wiki/Duineser_Elegien, dostęp: 19.03.2020. 
flattern zu sehen. Und das Totsein ist mühsam und voller Nachholn, daß man allmählich ein wenig Ewigkeit spürt. - Aber Lebendige machen alle den Fehler, daß sie zu stark unterscheiden. Engel (sagt man) wüßten oft nicht, ob sie unter Lebenden gehn oder Toten. Die ewige Strömung reißt durch beide Bereiche alle Alter immer mit sich und übertönt sie in beiden.

Zaprawdę, to osobliwe, nie przebywać już odtąd na ziemi, wyuczone zaledwie porzucić zwyczaje, różom i innym odrębnie obiecującym rzeczom nie dawać znaczeń ludzkiej przyszłości, już nigdy. Tym, czym się było w dłoniach tak nieskończenie trwożnych, nie być już więcej i nawet własne swe imię porzucić, jak się porzuca połamaną zabawkę. To osobliwe, już nie mieć życzeń. To osobliwe, wszystko, co było związane, ujrzeć w przestrzeni rozpierzchłe. A być umarłym to trud i doganianie straty, aby odczuć powoli cząstkę wieczności. - Lecz żyjący wciąż popełniają wszyscy ten błąd, że odróżniają zbyt mocno.

Anioły - jak niesie wieść - często nie wiedzą, czy idą między żywymi czy umarłymi. Prąd wieczny przez oba kręgi porywa pokolenia ludzkie, unosząc wiecznie ze sobą i zagłusza je w obu (Pierwsza elegia, w. 69-85) ${ }^{22}$.

Dość wyraźnie widać, że stan, w jakim coś takiego jak eschaton może subtelnie zwrócić na siebie uwagę, oscyluje między śmiercią dosłowną a metaforyczną. Ten na poły pośmiertny status „nie przebywania już odtąd na ziemi” i „trud” (mühsam) „bycia umarłym” (Totsein) opisywany jest tutaj jako stopniowe przechodzenie, raczej zmiana habitusu niż nagłe i kategoryczne zerwanie. Zbyt często bowiem „żyjący wciąż popełniają/ wszyscy ten błąd, że odróżniają zbyt mocno”. Wyzwanie dla współczesnego człowieka to zaakceptować „brak podstawy” (Bodenlosigkeit) i „różom (...) nie dawać znaczeń ludzkiej przyszłości”. Wyrzec się natomiast trzeba nie transcendencji jako takiej, lecz błędnych prób zarażenia tego świata transcendentnymi znaczeniami. Młody półbóg, który umarł przedwcześnie (motyw ten wraca w elegiach Rilkego nie rzadziej niż u prekursorów tego gatunku w klasycznej Grecji), zdradza tym, którzy pozostają przy życiu, „wielkie tajemnice” (grossel Geheimnisse - w. 88-89). Jedynie ostateczna utrata może dać nam imaginacyjny wstęp do „zatrwożonej przestrzeni (...)

${ }^{22}$ Tamże. 
próżni” („der erschrockene Raum, (...) das Leere” - w. 93-94), domeny, która niespodziewanie rezonuje także w nas - „nas porywa, pociesza, wspomaga” („die uns jetzt hineisst, tröstet und hilft” - w. 95).

\section{III}

Zarówno w późnej poezji Rilkego, jak i Eliota ewoluuje idiom, który uniemożliwia nam oddzielanie znaczenia dosłownego od metaforycznego, rzeczywistego (empirycznego) wzroku (visus) od epifanicznej wizji (visio). Dla Eliota oznacza to kształtowanie formy pisarskiej „pomiędzy zwykłymi tematami poezji a wierszami "nabożnymi«" (,between the usual subjects of poetry and 'devotional' verse"; list do Williama Force’a Steada, 8 września 1930 roku). Cztery kwartety Eliota, napisane między rokiem 1936 a 1943, przede wszystkim dotyczą umiejscowienia „Punktu przecięcia z czasem/ Bezczasowego (...) niemożliwej unii/ Sfer istnienia” („the point of intersection of the timeless/ With time (...) the impossible union / Of spheres of existence"; The Dry Salvages, w. 201, 217). Tak jak w wypadku Elegii duinejskich Rilkego medytacja Eliota nad stosunkiem między bezruchem, ciszą a ruchem i nad wyczekiwaną „wolnością od wewnętrznych/ I zewnętrznych przymusów” („release from the inner/ And the outer compulsion”, Burnt Norton, w. 71) nie traktuje tych stanów jako trwałych kontrastów. Wręcz przeciwnie, wyłącznie poprzez medium czasowo-przestrzennego doświadczenia mogą się objawić upragniona „niepełna ekstaza” (partial ecstasy) i „łaska zmysłów” (a grace of sense). Eliot nie jest mistykiem i „rozwiązanie”, o którym mówi, nie wiąże się z jakiegoś rodzaju nieopisywalnym „przeobrażeniem”, lecz jest „Wplecione w słabość nietrwałego ciała” (,Woven into the weakness of the changing body"; Burnt Norton, w. 73, 77, 80).

Na koniec chciałbym zatem krótko skupić się na drugim z Czterech kwartetów Eliota, East Coker, napisanym w pierwszych dniach drugiej wojny światowej i opublikowanym w maju 1940 roku. Tytuł odnosi się do wioski w hrabstwie Somerset, z której pochodził szesnastowieczny przodek Eliota, Sir Thomas Elyot, autor pierwszego $\mathrm{w}$ język angielskim traktatu o edukacji, do którego przelotnie odnosi się tekst Eliota. Inspiracji dla słynnego pierwszego wersu wiersza „In my beginning is my end” (Krzysztof Boczkowski: „W moim początku jest mój kres”), który w odwróconej kolejności zamyka wiersz: „In my end is my beginning” (Boczkowski: „W moim kresie jest mój początek”) - szukano u niezliczonych postaci, w tym u Heraklita, Guilllaume’a de Machaut, Marii królowej Szkotów, Lancelota Andrewesa i Johna Donne'a. Anglia kolejny raz jest na wojnie, a wspomnienie Eliota o wizycie w miejscu zamieszkania jego przodków z 1937 roku szybko ewoluuje w medytację na temat nietrwałości rzeczy, tego, jak „Kolejno/ Domy wznoszą się i upadają, niszczeją, są rozbierane,/ usuwane" (East Coker, w. 1-3) i tak dalej. Odwołując się do trzeciego rozdziału 
Księgi Koheleta („Wszystko ma swój czas (...). Jest czas rodzenia i czas umierania (...), czas zabijania i czas leczenia”), Eliot rozmyśla nad tym, czy błędny ludzki czas (zarówno przednowożytny i cykliczny, jak i nowożytny i sekwencyjny) mógłby ujawnić wzorzec o znaczeniu eschatologicznym. Jednakże, o ile takie wzorce w ogóle da się zidentyfikować, to mogą one rozpraszać lub zwodzić. Gdyż, jak odnotowuje Eliot:

there is...

At best, only a limited value

In the knowledge derived from experience.

The knowledge imposes a pattern, and falsifies,

For the pattern is new in every moment

And every moment is a new and shocking

Valuation of all we have been.

Jest, jak się wydaje,

W najlepszym razie, tylko przybliżona wartość

W wiedzy wynikłej z doświadczenia.

Wiedza narzuca wzór i przez to spacza,

Gdyż wzór jest nowy w każdej chwili,

A każda chwila jest nową i szokującą

Oceną tego, czym byliśmy (East Coker, w. 81-87)23.

Każdy wysiłek artystyczny, intelektualny lub religijny polega na „usiłowaniu” zrozumiałej mowy, i zawsze sprowadza się tylko do „nowego początku, wypadu w niewysłowione/ Z lichym ekwipunkiem niszczejącym zawsze". Natomiast z czasem „Świat staje się dziwniejszy, bardziej zawiły wzór” (East Coker, w. 178179, 191). Choć poezja, wraz z modlitwą, może w istocie być najbardziej rozpowszechnioną próbą skłonienia logosu, by się ujawnił, ludzka mowa nie może się pozbyć swojej skończoności. Może jedynie zapoczątkowywać, lecz nigdy doprowadzać do końca, poszukiwanie pełni, które z tego powodu Eliot i Rilke umiejscawiają w apofatycznej domenie ciszy i bezruchu. Jak mówi Eliot: „Słowa po wypowiedzeniu/ Docierają do ciszy. Tylko forma, wzór/ Mogą dać słowom albo dźwiękom/ Bezruch" (Burnt Norton, w. 139-142). Część druga East Coker kończy się przejmującą refleksją na temat pokory, ewidentnie zaczerpniętą z reguły św. Benedykta, w której podkreślone jest centralne miejsce i wzajemne powiązanie posłuszeństwa, pokory i ciszy: „Jedyna mądrość - którą możemy osiągnąć,/ Jest mądrością pokory: pokora jest nieskończona” (East Coker, w. 97-98).

W części trzeciej East Coker dominuje symbolika apokaliptyczna, która wraz z aluzjami do Dantego, Johna Miltona i św. Jana od Krzyża przedstawia ciemną

${ }^{23}$ T.S. Eliot, Cztery kwartety: East Coker, dz. cyt., s. 264. Tekst oryginalny cytowano za: https://www.fadedpage.com/books/20191242/html.php, dostęp: 19.03.2020. 
noc duszy współczesności. W listopadzie 1939 roku ta noc ogarnia wszystkich londyńczyków schodzących do tuneli metra (,istoty puste w pustkę” - w. 102) w trakcie niemieckiego nalotu. W mitycznej symbolice Eliota ten zarządzony stan wyjątkowy staje się tropem współczesnej egzystencji. Gdy „Kapitanowie, bankierzy, znakomici pisarze, (...)/ Potężni przemysłowcy, drobni handlarze" (w. 104, 107) razem „odchodzą w ciemność” (w. 102), ich wewnętrzna pustka jest demaskowana przez nieuchronne wymazanie znanej im rzeczywistości na powierzchni ziemi. Czerpiąc z barokowej metafory teatrum mundi, traktującej empiryczną rzeczywistość jedynie jako sztukę i inwencję sceniczną, Eliot odkrywa, że destrukcja dokonująca się na powierzchni wywołuje fundamentalną zmianę wewnątrz, powoduje ruch ku stanowi doskonałej ciszy i prostolinijnego wyczekiwania:

we all go with them, into the silent funeral,

Nobody's funeral, for there is no one to bury.

I said to my soul, be still, and let the dark come upon you

Which shall be the darkness of God. As, in a theatre,

The lights are extinguished, for the scene to be changed

With a hollow rumble of wings, with a movement of darkness on darkness,

And we know that the hills and the trees, the distant panorama

And the bold imposing facade are all being rolled away

(...)

I said to my soul, be still, and wait without hope

For hope would be hope for the wrong thing; wait without love,

For love would be love of the wrong thing; there is yet faith

But the faith and the love and the hope are all in the waiting.

Wait without thought, for you are not ready for thought.

I wszyscy podążamy z nimi w milczącym orszaku,

Na niczyim pogrzebie, bo grzebać nie ma kogo.

Powiedziałem duszy mej, bądź spokojna i pozwól by ciemność zstąpiła na ciebie,

Bo będzie to ciemność Boga. Jak w teatrze -

Światła zostały zgaszone, by zmienić scenę

Z pustym dudnieniem kulis, z przesunięciem ciemności na ciemność;

I wiemy, że wzgórza i drzewa, daleka panorama

I duma, imponująca fasada zostały uprzątnięte

(...)

Powiedziałem duszy mej, bądź spokojna, czekaj bez nadziei,

Bo byłaby nadzieją niewłaściwych rzeczy; czekaj bez miłości,

Bo byłaby miłością niewłaściwych rzeczy; jest jeszcze wiara,

Ale wiara, nadzieja i miłość - wszystkie są w oczekiwaniu.

Czekaj bez myśli, bo nie jesteś gotowa do myśli (East Coker, w. 110-127)24.

${ }^{24}$ Tamże, s. 266-267. 
Należy przypomnieć, że pierwotny sens greckiego słowa apokalypsis to nie jakieś przerażające rozerwanie dokonujące się w obrębie czasu historycznego, lecz odkrywanie i ujawnianie tego, co znajduje się poza granicami skończonej, czasowej egzystencji. Z tego powodu autorzy łacińscy ostatecznie oddadzą apokalypsis przez revelatio. Gdy na początku drugiej części East Coker chwilowo uruchamia się katastroficzny ton, gdy wiersz mówi o początku drugiej wojny światowej („Skorpion na Słońce się wyprawia (...). Komety w płacz a Leonidy/ Bieżą na połów niebios"; w. 61-63), Eliot szybko się z niego wycofuje. Prześmiewcze odrzucenie takich wersów jako „Studium peryfrastycznego w zużytym poetyckim sposobie" (w. 69) oddaje głębszą refleksję nad tym, że prawdziwa apokalipsa jest poza zasięgiem ludzkiej mowy. Dlatego należy aspirować do stanu bezruchu, nie sprawności retorycznej („Powiedziałem duszy mej, bądź spokojna”), jako że ludzka mowa - w tym także poezja - może tylko odzwierciedlać minione wzorce, które nieuchronnie zaburzy „Bo czegożeśmy jedynie nauczyli się: przechytrzać słowa;/ By ująć rzecz - już dla nas bez znaczenia, lub styl wynaleźćl Nie wart uwagi” (East Coker, w. 177-178). Odwrotnie, jedyny realny związek z przyszłością może mieć dyscyplina umysłowa, polegająca na byciu „w oczekiwaniu”, czyli na kultywowaniu cnót teologicznych (nadziei, wiary i miłości) niezależnie od ich przedmiotów i bez oczekiwania na spełnienie. Jak powiada Eliot pod koniec East Coker: „Miłość jest wtedy najbardziej sobą,/ Gdy »tu« i »teraz« traci swe znaczenie" (w. 201).

W Czterech kwartetach Eliot przywołuje kilka niezwykle paradoksalnych sposobów doświadczania czasu. Weźmy takie gnomiczne wersy, jak „być świadomym, znaczy nie być w czasie,/ Choć tylko w czasie - chwila w różanym ogrodzie, (...)/ Chwila w kościele, gdy opadał dym,/ Mogą być pamiętane" (Burnt Norton, w. 83-88). W momencie pełnej świadomości zawieszony jest czas chronometryczny. Być świadomym jakiegoś zjawiska, choćby ulotnego i zróżnicowanego, znaczy doświadczać czasu epifanicznego i objawieniowego. Tutaj świadomość zostaje tak całkowicie pochłonięta przez swój przedmiot, że nie może sobie nawet siebie wyobrazić jako odrębnej od niego w wymiarze czasowym lub przestrzennym. Epifaniczne momenty świadomości nie mieszczą się $\mathrm{w}$ przepływie czasu ani mu nie podlegają; nie wiążą się z nimi ,ani ruch, ani bezruch" (Burnt Norton, w. 63). Być świadomym to osiągnąć obecność, to znaleźć się „W wirującego świata - nieruchomym punkcie. Ani cielesnym, ani bezcielesnym,/ Ani od, ani do" (w. 62-63). Niezależnie od tego, jak konstytuowana jest taka obecność, jej pełnię zawsze będziemy wyczuwać, zanim zdołamy zapamiętać i nazwać jej poszczególne aspekty. W niewyjaśniony sposób wyłaniamy się z mgły skończonego, ciągle upływającego czasu i jesteśmy „otoczeni/ Łaską zmysłów" (Burnt Norton, w. 72-73), a obecność nie ma tu charakteru tylko symbolicznego czy hipotetycznego, lecz realny.

Mimo wszystko świadomość musi ostatecznie wrócić do porządku czasu, by ująć w pamięci i w mowie to, co właśnie się wydarzyło. Epifanie Eliota w niczym nie przypominają romantycznych subiektywnych wzlotów imaginacji 
i symbolistycznych twierdzeń dotyczących wzniosłych prawd. Modernistyczne teksty epifaniczne odpowiadają temu, co od $\mathrm{V}$ wieku naszej ery było znane jako teologia apofatyczna (negatywna), czyli świadomość zarówno obecności Boga, jak i niemożliwości i niedopuszczalności orzekania o określonych przymiotach Boga. Epifanie Eliota nie wyciągają z tego ograniczenia wniosków sceptycznych, lecz rozwijają się jako stały ruch w przód i w tył, swego rodzaju ruch dialektyczny między porządkiem transcendentnym i czasowym. Jest to ruch między tym, co Eliot określa jako „zarówno nowy świat,/ Jak i stary - jasne, zrozumiałe/ W spełnieniu swojej niepełnej ekstazy" (Burnt Norton, w. 75-76), między bezwarunkową pełnią i pewnością a opóźnioną, fragmentaryczną wiedzą o tym zjawisku. Dla Charlesa Taylora modernistyczna epifania typowo „wyłania się tu jak gdyby spomiędzy obrazów i słów”25 i jako taka „jest to epifania czegoś dostępnego jedynie pośrednio" ${ }^{26}$. Jednak ten stan zawieszenia „pomiędzy” doczesnością i transcendencją sam w sobie jest czymś, czego możemy być świadomi. I to ta świadomość pokazuje, że nasz związek z czasem obejmuje coś więcej niż nieszczęsne „bycie-ku-śmierci”, o którym mówi Heidegger. Ta koncepcja egzystencjalistyczna jest nam rzucana na pocieszenie właśnie w tych momentach, gdy epifaniczna świadomość ustępuje i wracamy do skończonego czasu. Przez ten powrót bowiem świadomość stanowczo przemienia się dzięki „łasce zmysłów", nie wraca niezmieniona do powszedniej, świeckiej egzystencji. Zatem osoba, która wróciła do zwykłego czasu, będzie odtąd świadoma tej epifanii, mimo iż świadomość musi próbować się bronić przed pełnią i obecnością, której nikt nie potrafi wytrzymać zbyt długo. Jak powiada Eliot:

Jednak to skucie - przeszłości z przyszłością

Wplecione w słabość nietrwałego ciała,

Chroni ludzkość od nieba i od potępienia

- Których by ciało nie zniosło.

(...)

Tylko przez czas - czas jest pokonany (Burnt Norton, w. 79-82, 89) ${ }^{27}$.

Aby przeczytać ostatni wers ze zrozumieniem, musimy się zatrzymać dokładnie w jego połowie, gdzie poprzez zaskakujące powtórzenie słowa kluczowego dla tego poematu Eliot czyni aluzję do dialektycznej natury naszej ograniczonej

${ }^{25}$ Ch. Taylor, Źródta podmiotowości. Narodziny tożsamości nowoczesnej, tłum. M. Gruszczyński i in., oprac. T. Gadacz, wstęp A. Bielik-Robson, Warszawa 2012 (rozdz. XXIV - Epifanie modernizmu, tłum. Ł. Sommer), s. 856.

${ }^{26}$ Tamże, s. 862. Zob. też: tamże, s. 879-880: „Przy tego rodzaju epifanii wcale nie potrzeba jakiegoś określonego przedmiotu. Słowa mogą stanowić ramę lub połączenie tych częściowo spójnych obrazów, które przed nami ustawiają. Znaczna część współczesnej poezji działa w ten właśnie sposób. Być może nie zachodzi tu następstwo wyraźnie określonych obrazów, ale już samo zakłócenie i napięcie w tym, co zostało przywołane, ustanawia przestrzeń epifanii”.

27 T.S. Eliot, Cztery kwartety: Burnt Norton, dz. cyt., s. 238-239. 
czasem egzystencji. Zatem ostatecznie to nasza zdolność uchwycenia w obrębie porządku czasu chwil i znaczeń wskazujących poza niego dla Eliota (bardziej niż dla Rilkego) podtrzymuje trwałość eschatologii w liberalno-sekularnej współczesności.

Ttumaczenie Jakub Czernik

\section{Bibliografia}

Balthasar H.U. von, Das Ganze im Fragment, Einsiedeln 1963.

Eliot T.S., Cztery kwartety: Burnt Norton, tłum. K. Boczkowski [w:] tegoż, Wybór poezji, wyb. K. Boczkowski, W. Rulewicz, wstęp W. Rulewicz, Wrocław 1990, BN II 230.

Eliot T.S., Cztery kwartety: East Coker, tłum. K. Boczkowski [w:] tegoż, Wybór poe$z j i$, wyb. K. Boczkowski, W. Rulewicz, wstęp W. Rulewicz, Wrocław 1990, BN II 230.

Heidegger M., Bycie i czas, tłum., przedm., przyp. B. Baran, Warszawa 2004.

Nietzsche F., Tako rzecze Zaratustra, tłum. W. Berent, Kraków 2014.

Pascal B., Myśli, tłum. T. Żeleński (Boy), Warszawa 1968.

Ratzinger J., Śmierć i życie wieczne, tłum. M. Węcławski, Warszawa 2000.

Rilke R.M., Elegie duinejskie, tłum. M. Jastrun, Kraków 1962.

Rilke R.M., Malte. Pamiętniki Malte-Lauridsa Brigge, tłum. W. Hulewicz, https:// wolnelektury.pl/media/book/pdf/rilke-malte.pdf, dostęp: 19.03.2020.

Taylor Ch., Źródta podmiotowości. Narodziny tożsamości nowoczesnej, thum. M. Gruszczyński i in., oprac. T. Gadacz, wstęp A. Bielik-Robson, Warszawa 2012 (rozdz. XXIV - Epifanie modernizmu, tłum. Ł. Sommer). 